\title{
Development of a Platform for Augmented Reality- Based Speech Language Therapy
}

\author{
In-Ho Bae ${ }^{\mathrm{a}}$, Ju-A Lee ${ }^{\mathrm{b}}$, Hee-June Park ${ }^{\mathrm{c}}$, Soon-Bok Kwon ${ }^{\mathrm{d}}$ \\ ${ }^{a}$ Department of Otorhinolaryngology, Pusan National University Yangsan Hospital, Yangsan, Korea \\ ${ }^{b}$ Cheum Speech-Language Psychology Sensory-Integration Development Center, Yangsan, Korea \\ 'Department of Speech Rehabilitation, Choonhae College of Health Sciences, Ulsan, Korea \\ ${ }^{d}$ Department of Language and Information, Pusan National University, Busan, Korea
}

Correspondence: Soon-Bok Kwon, $\mathrm{PhD}$ Department of Language and Information, Pusan National University, 2 Busandaehak-ro 63beon-gil, Geumjeong-gu, Busan 46241, Korea

Tel: +82-51-510-1518

Fax: +82-51-582-0572

E-mail: sbkwon@pusan.ac.kr

Received: April 16, 2018

Revised: May 28, 2018

Accepted: June 4, 2018

This work was supported by the Ministry of Education of the Republic of Korea and the National Research Foundation of Korea (No. NRF2015S1A5B6037281).

\begin{abstract}
Objectives: In the field of speech language therapy, augmented reality (AR) is being treated with interest as a new medium to complement the traditional therapy paradigm. The purpose of this study was to develop a program for markless AR-based speech language therapy using tablets and to compare the effects of AR and picture card intervention. Methods: AR applications were programmed to recognize objects using natural feature tracking algorithms, and 3 children with specific language impairment participated in AR and picture card-based intervention with 24 action verbs in an alternating treatment design. The differences between the two interventions were compared in vocabulary accuracy, improvement rate difference, flow, and learning interest. Results: Improvement in action verb vocabulary was shown in both the AR-based intervention and the picture card intervention, with the AR-based intervention resulting in higher vocabulary accuracy in the intervention and maintenance phase. Additionally, the AR-based intervention showed higher learning flow. General interest was similar in both intervention methods, but the AR-based intervention was higher in situation interest. Conclusion: AR-based intervention was effective for learning vocabulary that would normally be taught with conventional picture cards; mixed reality AR helped improve children's learning motivation and participation levels. In addition, the markless AR platform has advantages for clinical speech language pathology practice because the content can be easily expanded.
\end{abstract}

Keywords: Augmented reality, Natural feature tracking, Specific language impairment, Action verb, Tablets
최근 기술기반 학습(technology-enhanced learning) 연구들은 증강현실 유비쿼터스 러닝, 모바일 러닝, 가상현실 등을 이용하여 사용자 경험과 만족도를 향상시키기 위한 새로운 기술에 초점을 맞추고 있다. 증강현실 또한, 모바일 장치 및 하드웨어와 소프트웨 어 기술의 혁신과 함께 기술의 접근성이 높아져 사용자 중심의 학 습 프로세스 개발에 활용되고 있다(Bai, Blackwell, \& Coulouris, 2015). 증강현실은 가상현실에서 파생된 분야로, 현실세계에 가상 세계를 겹쳐 혼합현실에서 사용자와 상호작용하게 하는 기술이다. 다시 말해, 실제 환경에 가상의 오브젝트를 투영함으로써 원래 환 경에 존재하는 사물처럼 보이게 하는 컴퓨터그래픽기법이다.

스마트폰과 태블릿 등의 보급이 일반화되면서 현실세계에 이미
지나 문자 등의 정보를 제공하는 개념을 넘어 증강현실의 영역은 급속도로 발전되고 있다. 기술을 실현하는 인간과 컴퓨터 상호작 용(human computer interaction, HCI)의 특징에 따라 다양한 형태 로 적용이 가능하다(Bacca, Baldiris, Fabregat, \& Graf, 2014; Choi, Kim, Yeon, Kim, \& Hong, 2016; da Cunha, Neiva, \& da Silva, 2018; Kang, Park, Song, Kim, \& Shin, 2015; Lee, Kang, \& Kim, 2013). 일 례로 증강현실에 대한 인식을 대중화하는 데 큰 역할을 한 '포켓몬 Go'는 증강현실 기술을 이용하여 현실(실제 환경이나 배경)과 가 상(캐릭터)을 결합한 게임으로, 사람의 눈으로 인식할 수 있는 현실 세계에 포켓몬이라는 가상의 객체를 덧입혀 혼합현실을 구현하였 다. 평창올림픽 개막식에서도 증강현실을 이용하여 '천상열차분야 
지도'를 재연하였고, 'AR ways' 애플리케이션을 통하여 좌석을 찾 아갈 수 있도록 하였다. 이처럼, 증강현실은 게임뿐만 아니라 수술, 공사현장, 공연산업 등에서 적극적으로 활용되고 있다.

교육 분야에서는 증강현실 기반의 학습환경을 구성하기 위한 교 육콘텐츠의 개발이 시도되어 왔고 학습성취와 효능성에서 효과적 이라고 보고되고 있다(Kye \& Kim, 2008). 특수교육과 언어치료 분 야에서도 기존의 전통적인 치료교구를 보완할 새로운 매체에 대한 관심이 높아지면서 애니메이션을 이용한 치료, 기능성 게임, 증강 현실을 이용한 치료프로그램들이 소개되고 있다(Bai et al., 2015;

Chen, Lee, \& Lin, 2016; da Silva, Fernandes, \& Grohmann, 2014;

Herrera et al., 2008; Schlosser et al., 2012).

2000년대 이후로 증강현실을 이용한 치료들이 관심을 받기 시 작하였으며 자폐아와 같이 인지능력이 부족하고 현실세계에 적응 하기 힘들어하는 아동을 대상으로 연구가 활발히 진행되었으며 현 실과 가상 콘텐츠의 결합은 자폐아의 주변환경에 대한 이해를 향 상시키는 데 도움이 되었다(Chen et al., 2016; da Silva et al., 2014). 증강현실의 학습효과는 대부분의 연구에서 긍정적인 결과를 나타 내었으나 Chung, Vanderbilt와 Soares (2015)는 아동의 흥미를 유 발할 수는 있지만 학습효과와 사회화 효과에서는 부정적인 결과 를 나타내었으며 Lee와 Ryu (2014)는 증강현실 자체보다 전통적 치 료와 결합되었을 때 더 나은 효과를 얻을 수 있다고 보고하였다.

국내에서는 Choi, Kim과 Kim (2013)의 연구를 시작으로 증강 현실을 이용한 치료효과에 대한 검증, 증강현실 시스템 디자인, 증 강현실 적용에 따른 대상자와 교육자의 반응 등 다양한 연구들이 진행되었다(Kim \& Kwon, 2017). 언어치료 분야에서도 Bae, Park, Kim과 Kwon (2014)이 단순언어장애 아동을 대상으로 증강현실 을 치료프로그램을 이용하여 치료효과를 검증하였고 텍스트 기 반 프로그램과 비교하여 치료효과는 유사하나 몰입과 학습흥미 에서 더 나은 결과를 나타내었다고 보고하고 있다. 또한, Lee (2018) 는 증강현실 기반 애플리케이션을 활용하여 언어발달지체 아동의 동사표현을 중재하였고 동사표현의 증가와 그림카드로의 일반화
를 확인하였다. Ahn, Bae, Park과 Kwon (2018)은 지적장애 아동을 대상으로 동적인 변화를 나타내는 어휘학습에 효과가 있음을 확인 하였다.

언어치료현장에서는 서지 기반의 치료교구들이 주류를 이루며 최근 들어 스마트폰과 태블릿을 활용한 치료들이 적용되고 있지만 정보통신기술을 활용한 치료접근들은 플랫폼과 콘텐츠의 부재, 사용성의 제한 등으로 적절하게 활용되고 있지 못하다. 증강현실 은 하나의 기술임으로 임상현장에서 증강현실을 이용한 중재 접근 성을 높이기 위해서는 $\mathrm{HCI}$ 관점에서 사용자 경험에 기반한 서비스 플랫폼의 개발이 선행되어야 하며 이를 지원하기 위한 다양한 콘텐 츠의 개발이 필요하다(da Cunha et al., 2018). 그러나 아직까지 국 내외에서 증강현실을 언어치료에 접목한 연구들이 많지 않다.

따라서, 본 연구에서는 증강현실을 언어치료에 적용하기 위한 태 블릿 컴퓨터 기반 애플리케이션과 콘텐츠를 개발하고 이를 시도적 으로 언어치료에 적용하여 그림카드 기반중재와비교해보고자한다.

\section{연구방법}

\section{연구대상}

이 연구에서 개발된 증강현실 언어치료프로그램의 적용 가능성 을 살펴보기 위하여 경남지역 언어치료실에서 다니는 단순언어발 달지연 아동 3 명을 대상으로 연구를 진행하였다. 취학전 아동의 수 용언어 및 표현언어 발달척도(Preschool Receptive-Expressive Language Scale, PRES; Kim, Sung, \& Lee, 2003)에서 언어발달이 1년 이상 지연된 아동, 한국 웩슬러유아지능검사(Korean-Wechsler Preschool and Primary Scale of Intelligence, K-WPPSI; Park, Kwak, \& Park, 1996)에서 지능지수 85 이상인 아동, 신체적 장애가 없으며 태블릿 컴퓨터 조작에 제한이 없는 아동을 대상으로 하였다.

대상아동들의 일반적인 특성은 Table 1 과 같다. 행동특성을 살 펴보면, 대상자 1 은 주의집중 시간이 짧았으며 치료사와의 일대일 대면에서 산만하였다. 자동차와 로봇 등 자신이 관심 있는 사물에

Table 1. Individual characteristics of subjects

\begin{tabular}{|c|c|c|c|c|c|c|}
\hline \multirow{2}{*}{ Subject no. } & \multirow{2}{*}{ Sex } & \multirow{2}{*}{ Age (mo) } & \multicolumn{2}{|c|}{ PRES } & \multirow{2}{*}{$\begin{array}{c}\text { KM-B CDI } \\
\text { expressive verb }\end{array}$} & \multirow{2}{*}{ K-WPPSI IO } \\
\hline & & & $\mathrm{RLA}(\mathrm{mo})$ & $\mathrm{ELA}(\mathrm{mo})$ & & \\
\hline 1 & Male & 50 & 41 & 35 & 73 & 102 \\
\hline 2 & Male & 48 & 40 & 31 & 61 & 108 \\
\hline 3 & Male & 47 & 37 & 33 & 69 & 110 \\
\hline Mean & & 48.3 & 39.9 & 33.0 & 67.7 & 106.7 \\
\hline
\end{tabular}

PRES=Preschool Receptive-Expressive Language Scale (Kim, Sung, \& Lee, 2003); RLA= receptive language age; ELA= expressive language age; K M-B CDI=Korean MacArthur-Bates Communication Development Inventories (Pae \& Kwak, 2011); K-WPPSI=Korean-Wechsler Preschool and Primary Scale of Intelligence (Park, Kwak, \& Park, 1996). 
In-Ho Bae, et al. • Markless Augmented Reality based Speech Language Therapy

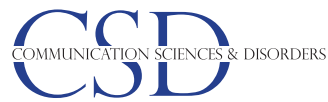

대하여 적극적인 상호작용을 시도하였으나 발화보다는 행동위주 의 활동이 주를 이루었다. 대상자 2는 내성적인 성격으로 어머니의 눈치를 많이 보며 자발적으로 사물을 요구하는 빈도가 낮았고 문 장을 끝까지 완성하지 못할 때가 많았다. 그러나 한 가지 사물에 대 한 주의집중이 높았으며 수업태도가 우수하였다. 대상자 3은 치료 사가 제시한 상황에 대하여 주제를 유지하며 주고받기 대화가 원 활하였으며 발화량도 많았다. 그러나 정확한 어휘량이 부족하여 에둘러 말하기나삽입어를 많이 사용하였다.

\section{연구도구}

태블릿 기반 증강현실 언어치료프로그램을 구현하기 위해서는 콘텐츠, 서비스 플랫폼, 네트워크, 디바이스가 필요하다. 이를 위하 여, 그림카드와 $3 \mathrm{D}$ 모델을 제작하였고 마커 없이 이미지를 인식시 키기 위하여 Unity 3D 프로그램을 사용하여 이미지 탐지 모듈, 데 이터베이스 모듈, 랜더링 모듈, 트랙킹 모듈을 포함한 애플리케이션 을 제작하였다(Figure 1), 증강현실 프로그램은 안드로이드 기반

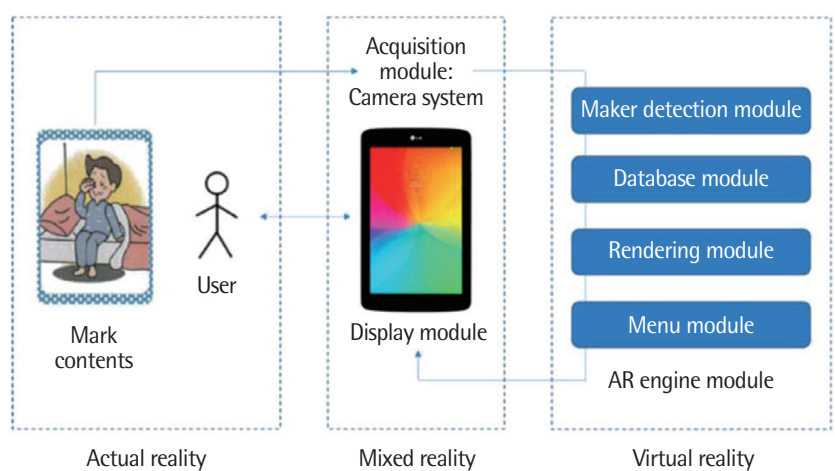

Figure 1. Schematic view of augmented reality (AR) program for speech language therapy.
G-pad III 10.1 (LG, Korea)에서 증강현실을 출력하였다.

\section{그림 카드}

증강현실은 그림카드를 통하여 $3 \mathrm{D}$ 모델을 현실세계로 불러올 수 있기 때문에 사물의 조작이 가능하며 움직임이 포함된 모델을 제시해줄 수 있다. 이러한 특징을 적절히 활용하기 위해서는 평면 의 그림카드에서 표현이 제한적인 역동적 움직임 또는 감정을 나타 내는 동사의 학습에 유용할 수 있다(Chen et al., 2016).

본 연구에서는 Hwang, Kwon, Kim과 Shin (2017)의 연구에서 역동적 움직임을 표현하는 동사로서 동작 타당도가 검증된 동작동 사 68 개를 이용하였고, 카메라를 통하여 $3 \mathrm{D}$ 오브젝트를 인출시키 기 위하여 개별 특징점 추출이 용이한 일러스트를 카드형태로 제 작하였다(Figure 2). 카드의 전면은 일러스트로, 후면은 문자로 구 성하여 증강현실과 함께 다양한 자극 수준에서 활용할 수 있도록 하였다.

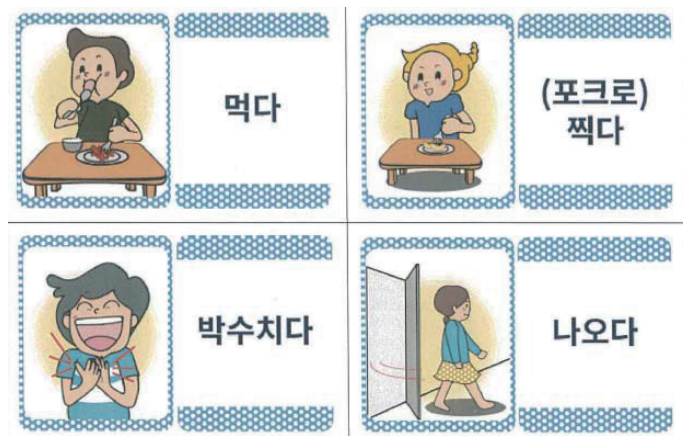

Figure 2. Example of action verb cards for vocabulary learning using augmented reality.
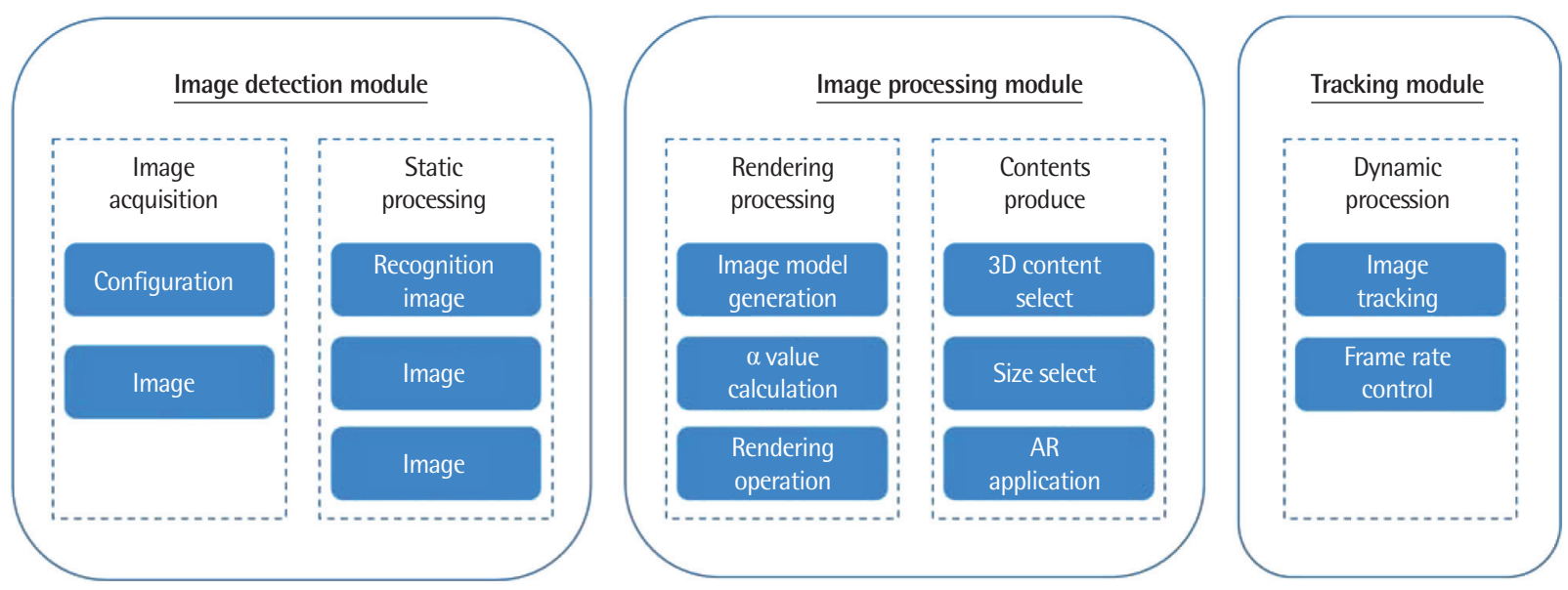

Figure 3. Flow chart of system module configuration. 


\section{증강현실 애플리케이션}

그림카드와 오브젝트를 일대일로 매칭시키기 위해서는 인식과 구현을 위한 증강현실 엔진 모듈이 필요하다. 애플리케이션은 Unity $3 \mathrm{D}$ 개발환경에서 C\#으로 Vuforia 라이브러리를 사용하여 개발 하였고 애플리케이션은 안드로이드 플랫폼에 구동되도록 하였다 (Figure 3).

마커로 증강을 인식하던 방식은 카드에 마크를 삽입하는 추가적 인 작업이 필요하기 때문에 장애특성에 따라 다양한 어휘목록의 확장이 필요한 언어치료에 있어 콘텐츠 확보에 제한점이 된다. 따라 서 본 연구에서는 특정마크의 제작 없이 그림카드 자체를 인식하 여 3D 오브젝트와 매칭하기 위하여 소벨연산(Sobel operator)과 라 플라시안(Laplacian)을 이용하여 그림의 가장자리를 특징점으로 추출하였다(Formula (1)).

$$
G_{x}=\left[\begin{array}{lll}
-1 & 0 & +1 \\
-2 & 0 & +2 \\
-1 & 0 & +1
\end{array}\right] * A \text { and } G_{y}=\left[\begin{array}{ccc}
-1 & -2 & -1 \\
0 & 0 & 0 \\
+1 & +2 & +1
\end{array}\right] * A
$$

소벨 연산은 $3 \times 3$ 크기의 행렬을 사용하여 연산을 하였을 때 중 심을 기준으로 각 방향의 앞뒤의 값을 비교하여서 변화량을 검출 하는 알고리즘이다. Formula (2)와 같이, 마스크의 특성상 이미지 의 $x$ 방향과 $y$ 방향으로 총 2 번 수행되고 기울기의 크기(magnitude of gradient)에 해당하는 Formula (3)을 간략화 한 $G=\left|G_{x}\right|+\left|G_{y}\right|$ 의 형태로 메그니튜드를 표현한다.

$$
\begin{aligned}
D_{x y}^{2} & =\left[\begin{array}{ccc}
0 & 1 & 0 \\
1 & -4 & 1 \\
0 & 1 & 0
\end{array}\right] \\
G & =\sqrt{G_{z}^{2}+G_{y}^{2}}
\end{aligned}
$$

소벨 연산을 추가로 미분한 경우, 영상처리에서 Formula (4)와 같이 정의되며 이를 라플라시안이라고 부른다. 이 연산자는 디지 털 2차 미분의 수식적 형태를 마스크로 가져온 것으로 Formula (3) 에서 픽셀 사이의 거리에 해당하는 $h$ 를 1 로 설정하면 마스크의 형 태가 얻어지는 것을 확인할 수 있다.

$$
\Delta f(x, y)) \approx \frac{f(x-h, j)+f(x+h, y)+f(x, y-h)+f(x, y+h)-4 f(x, y)}{h^{2}}
$$

코너점을 통하여 특정마크를 인식하면 그레이스케일로 변환하 고 분포군들의 차이로 그림카드를 인식한다(Figure 4). 카메라 영 상을 배경영상(background plan)으로 비디오 캡처자료로 연동되 고 영상에서 Vuforia에서 제공하는 마커 검출 알고리즘을 통하여 이미지 마커를 검출한다. 이후, 이미지 마커의 중심좌표를 반환하 고 3D 모델의 xyz좌표를 이미지 마커 중심좌표로 설정하여 콘텐 츠를 구현하였다.

영상인식은 태블릿 컴퓨터의 내장카메라를 이용하거나 별도의 외 장카메라를 연결하여 그림카드의 정보를 습득하도록 하였다. 증강현 실을 이용한 언어치료프로그램은 그림카드에 따라 4 개(방, 거실, 부 엌, 욕실)의 상황에서 목표어휘의 동작이 구연되도록 하였다. 치료상 황에서의 아동의 발화를 녹음할 수 있도록 하였으며 아동이나 치료 사의 조작에 따라 $3 \mathrm{D}$ 객체의 시점, 크기, 동작 등의 조절이 가능하다 (Figure 5). Ahn 등 (2018)의 연구에서는 장면단위로 구성하여 장소를 선택하고 목표단어를 선택하여 증강이 구현되도록 하였으나 이러한 방법은 하나의 마커로 다양한 증강을 구현할 수 있다는 장점이 있지 만 즉각적인 어휘변경이 어려워 몰입과 사용성을 저해하는 요소가 될 수 있다. 이를 보완하고자 그림카드 자체에 장소와 목표어휘를 포 함한증강을 매칭시켜 장면과 어휘의 변화를 용이하도록 하였다.

\section{실험 과정}

실험은 경남 소재 언어치료실에서 실시되었고 예비검사, 중재, 일 반화, 유지 단계로 진행하였고 중재 단계가 종료 후, 학습 몰입도
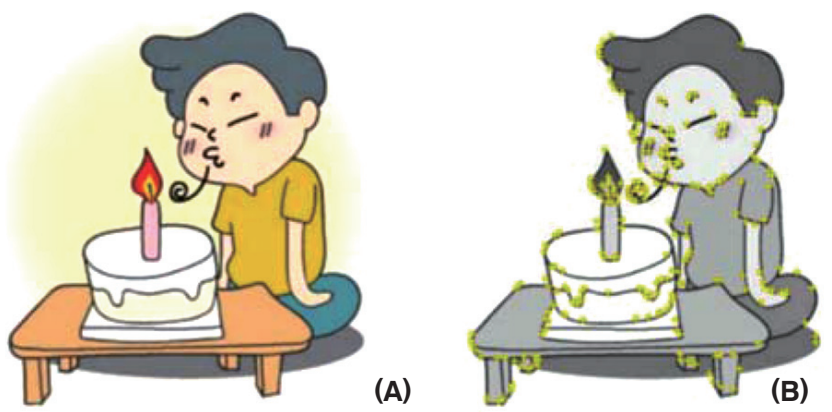

Figure 4. Image recognition of verb card using interesting point extract algorithm. (A) Original image and (B) grayscale image.
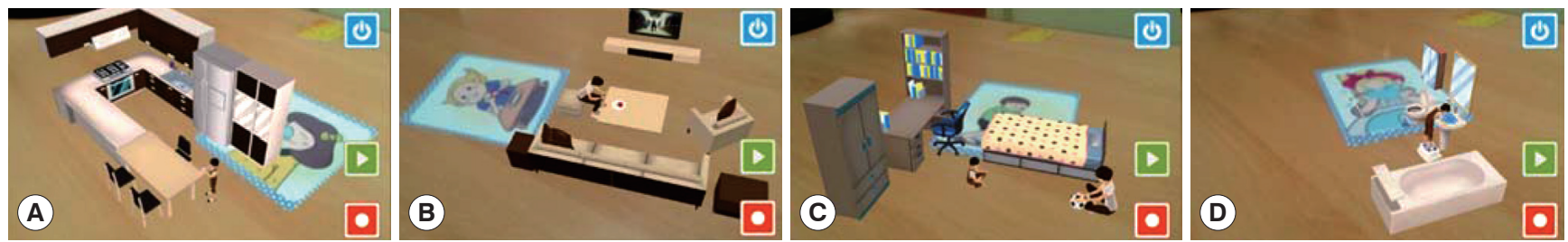

Figure 5. Mixed reality therapy program based on augmented reality. (A) Kitchen, (B) living room, (C) room, and (D) restroom. 
(learning flow)와 학습 흥미도(learning interest) 검사를 실시하였 다. 동적인 움직임을 나타내는 증강현실용 동사그림카드와 태블릿 컴퓨터 기반 증강현실 애플리케이션을 개발하여 증강현실 언어치 료 프로그램으로 사용하였고 그림카드 기반 언어치료는 '언어신장 카드', ‘재미있는 언어치료', ‘그림 동작어 사전'의 그림카드를 사용 하였다.

이를 3 명의 대상자에게 적용하여, 중재 간의 차이를 교대중재설 계(alternating treatment design)를 사용하여 살펴보았다. 교대중 재설계는 한 대상자에게 여러 중재를 회기 간 또는 회기 내에서 빠 르게 교대로 실시하여 그 중재들 간의 효과를 비교하는 연구방법 으로 체계적으로 중재간 균형을 맞춤으로써 중다중재설계가 가지 고 있는 내적타당도 문제와 중재 간 전이문제를 감소시킬 수 있다.

중재는 4년 이상의 경력을 가진 언어재활사에 의하여 일대일로 진행되었으며 오전과 오후에 두 중재가 교대로 적용되었다. 성숙에 의한 변인을 통제하기 위하여 아동의 보호자에게 오전과 오후 치 료 사이에 목표어휘에 대한 학습 또는 언급을 최대한 배제하도록 지시하였고 오전 치료 이후 충분한 휴식을 취하고 오후 치료에 오 게 하였다. 중재는 동일한 치료환경에서 30 분씩 주 6 회로 기초선, 중재, 유지 단계를 포함하여 총 15 회기 동안 실시되었다. 순서의 변 인을 통제하기 위하여 순서의 변인을 통제하기 위하여, Table 2의 어휘목록의 제시와 회기 내에서 중재방법의 적용 순서를 다르게 하여 실험을 실시하였다. 대상자 1 에서 증강현실(어휘목록 $\mathrm{A}$ ), 그림 카드(어휘목록 B), 증강현실(어휘목록 C), 대상자 2에서 그림카드 (어휘목록 $\mathrm{B})$, 증강현실(어휘목록 $\mathrm{C}$ ), 그림카드(어휘목록 $\mathrm{A}$ ), 대상 자 3에서 증강현실(어휘목록 $\mathrm{C}$ ), 그림카드(어휘목록 $\mathrm{B}$ ), 증강현실 (어휘목록 A) 순으로 번갈아 가며 시작하였다. 중재과정은 비디오 로 녹화되었다.

\section{예비검사}

예비검사를 통하여 실험에 사용할 어휘 24 개를 선정하였다(Table 2). 선정기준은 다음을 만족하는 동사들로 하였다. (1) 취학전 아동의 수용언어 및 표현언어 발달척도(Kim et al., 2003)와 한국판 맥아더-베이츠 의사소통발달평가 기록지(Pae \& Kwak, 2011)에서 세 대상자 모두가 표현이 되지 않는 동사, (2) Hwang 등(2017)이 동
작 타당도를 검증한 동사들을 이용하여 제작한 증강현실용 콘텐 츠에 있는 동사, (3) '언어신장카드', '재미있는 언어치료', '그림 동작 어 사전'에 그림카드가 있는 동사.

\section{중재 절차}

기초선 단계

기초선 단계에서는 예비검사에서 선정된 24 개 어휘의 증강현실 과 그림카드를 한 회기 내에서 대상자에게 각각 10 분씩 제시되었고 대상자 1 과 대상자 3 은 그림카드, 대상자 2 는 증강현실로 시작하여 회기마다 반대의 순서로 제시되었다. 아동에게 목표어휘의 동작에 대해 대답하도록 지시하였고 정오반응에 대한 피드백과 강화를 제 공하지 않았다.

\section{중재 단계}

중재를 실시하기 전, 아동이 표현 가능한 증강현실 카드를 제시 하여 아동에게 태블릿 컴퓨터 또는 카드를 조작하여 증강현실을 구연하는 방법을 연습시켰다. 증강현실 중재 또는 그림카드 중재는 도입(5분), 중재(20분), 평가(5분)으로 한 회기당 30 분씩 실시되었 다. 도입에서는 아동과 일상생활 대화를 하면 긴장을 풀고 금일 학 습할 내용과 방법에 대하여 설명하며 치료참여를 유도하였다. 중재 에서는 증강현실 또는 그림카드를 사용하여 동사를 학습시켰다. 중재과정은 아동이 태블릿 컴퓨터 또는 그림카드를 이용하여 목표 어휘를 자발화할 수 있도록 강화된 환경중심 언어중재(enhanced milieu teaching)에 근거한 놀이방식으로 시행되었다(Appendix 1). 일상생활에 근거한 상호작용에 초점을 맞추어 맥락적 상황제시, 요 구도 상승을 위한 도구조작, 불충분한 자료 제공, 선택하기, 요구-모 델하기, 시간 지연, 자극단서 수준별 제시 등의 전략을 사용하여 정 반응을 유도하였다(Kim, 2002; Snell \& Brown, 2008). 다양한 촉진 에도 아동이 정반응하지 않았을 시, 모방을 통한 반복학습을 실시 하였다. 두 중재 모두에서 $80 \%$ 이상 정반응을 보이거나 같은 어휘 목록을 4 회기 동안 학습한 경우에 다음 어휘목록으로 넘어가도록 하였고 모든 세트의 중재에서 준거에 부합하였을 때 중재를 종결하 였다. 평가는 회기 동안 학습한 내용을 확인하기 위하여 증강현실 또는 그림카드를 보여주며 정반응 유무를 확인하였고 정반응 시

Table 2. The list of action verbs

\begin{tabular}{|c|c|c|c|c|}
\hline & \multicolumn{4}{|c|}{ Action verbs } \\
\hline & Room & living room & Kitchen & Bath room \\
\hline $\operatorname{Set} A(N=8)$ & put in, put out, lie & attach, hold, & spill & wash, paint \\
\hline Set $B(N=8)$ & turn on, turn off, catch & clap, go into, go out & peel & comb \\
\hline $\operatorname{Set} C(N=8)$ & hang, hide & crawl, roll, sit & break, suck & wipe \\
\hline
\end{tabular}


사회적 강화를, 오반응 시 정답을 피드백 하여 주었다.

\section{유지 단계}

유지 단계는 중재 단계 종류 후 7일 후에 실시되었고 기초선과 동 일한 조건에서 총 3 회기 동안 실시하였다.

\section{자료 분석}

평가 신뢰도

어휘정확도 측정의 신뢰도를 살펴보기 위하여, 중재에 참여한 언 어재활사 1 인 외에 10 년 이상의 경력을 가진 1 급 언어재활사에 의 하여 녹화된 영상을 바탕으로 재평가가 실시되었다. 중재 회기의 $25 \%$ 를 무작위로 추출하여 시행되었고 평가자 간 신뢰도(일치한 항 목/일치한 항목+일치하지 않은 항목 $\times 100)$ 는 $100 \%$ 였다.

\section{중재 충실도}

중재 충실도(충실 1, 불충실 0)는 Schlosser 등(2012)의 연구를 참조하여 연구목적에 맞게 수정하여 이용하였다. 중재 회기의 녹 화 영상 $25 \%$ 를 무작위로 추출하여 사용하였고 언어치료학과 교수 1 인과 박사학위 1 급 언어재활사 1 인에 의하여 실시되었다. 중재충 실도(동일하게 충실로 평가한 문항/전체 문항 $\times 100$ )는 대상자 1,2 , 3 에서 각각 $90 \%, 90 \%, 100 \%$ 였다.

\section{어휘정확도}

프로그램의 중재 및 평가모드에서 정오반응(정반응 1 , 오반응 0 ) 을 기록함으로써 매 프로그램에서 채점되도록 하였고 백분율(정 반응 어휘수/전체 어휘수 $\times 100)$ 로 계산하였다.

\section{중재효과 크기}

중재효과의 크기를 보기 위하여, 기초선 단계와 중재 단계에서 개선율을 구하고, 두 개선율의 차(improvement rate difference, IRD)를 계산하였다(Formula (5)). IRD의 범위는 -1.0-1.0 사이로 .75 이상은 아주 높은 효과를 의미하며 음수 값은 중재의 부정적 효과를 의미한다(Parker, Vannest, \& Brown, 2009).

$$
\begin{gathered}
\text { IR (improvement rate) }=\frac{\text { Impreved data points }}{\text { Total points }} \\
\text { IRD (improvement rate difference) }=I R_{\text {Intervention }}-I R_{\text {Baseline }}
\end{gathered}
$$

\section{몰입 검사}

몰입은 현재의 활동을 최적의 경험으로 느끼게 되는 상태로 몰 입의 정도에 따라 치료진전 정도가 달라질 수 있다(Shelton \& Hed- ley, 2002). 이 연구에서는 Lee (2015)의 연구에서 사용한 몰입검사 를 참조하여 연구목적에 맞게 수정하여 사용하였고 중재 단계 이 후 중재 회기의 $25 \%$ 를 무작위로 추출하여 5 점 리커트 척도로 박사 학위 1 급 언어재활사 1 인에 의하여 실시되었다.

아동용 몰입척도는 치료사용 평정척도이며, 아동이 놀이를 위 한 명확한 목표설정과 자기조절, 활동의 인지, 문제해결과제에 대 한 도전과 해결과 관련된 문제해결능력 29개 문항, 치료사의 말과 활동에 집중하여 불필요한 정보와 자극에 주의를 기울이지 않는 것과 관련한 치료에 대한 집중 5 문항, 치료에 열중하여 자신의 행동 또는 모습을 의식하지 않는 것과 관련한 자의식의 상실 7문항, 치료 에 집중하면서 시간의 흐름을 빠르게 또는 느리게 느끼는 것과 관 련한 시간 전이 3 문항을 포함한 총 44 개 문항으로 구성되어 있다.

언어치료학과 교수 1 인과 박사학위 1 급 언어재활사 1 인에 의하여 문항타당도와 평가자 간 신뢰도가 평가되었고 평가자 간 신뢰도는 급내 상관계수(intra-class correlation, ICC) .864로 매우 높은 신뢰 도를 나타내었고 문항타당도는 4.1점으로 대체적으로 높은 타당도 를 보였다(ICC $=.891)$.

\section{학습 흥미도검사}

몰입검사와 함께 치료 흥미도검사가 실시되었다. 이 연구에서는 $\mathrm{Bae}$ 등(2014)이 증강현실 연구에 사용한 학습 흥미도검사를 사용 하였고 중재 단계 이후 박사학위 1 급 언어재활사 1 인에 의하여 실시 되었다. 보다 정확한 아동의 피드백을 얻기 위하여 검사자는 해당 문항에 대하여 아동이 알아들을 수 있게 반복하여 설명하였고 채 점지로 Fun Toolkit를 사용하였다(Figure 6). 학습 흥미도검사는 일 반적 흥미 20 문항과 처치 받은 치료 자체에 대한 흥미를 의미하는 상황적 흥미 5 문항을 포함하여 총 25 개 문항으로 구성되어 있다.

검사의 문항타당도는 언어치료학과 교수 1 인과 박사학위 1 급 언 어재활사 1 인이 5 점 리커트 척도로 검증하였고 4.4 점으로 대체적 으로 높은 타당도를 보였다(ICC $=.853)$.

\section{연구결과}

태블릿 컴퓨터 기반의 증강현실 애플리케이션과 콘텐츠를 개발

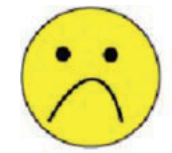

Awful

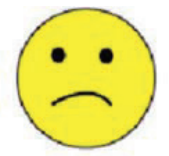

Not very good

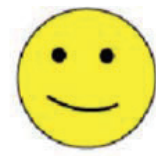

Good

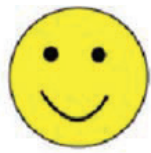

Really good

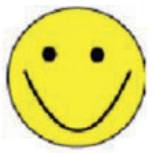

Brilliant
Figure 6. Survey methods to gather opinions of child (Read \& MacFarlane, 2006) 
In-Ho Bae, et al. • Markless Augmented Reality based Speech Language Therapy

Table 3. Results of response scores between AR and picture card-based intervention

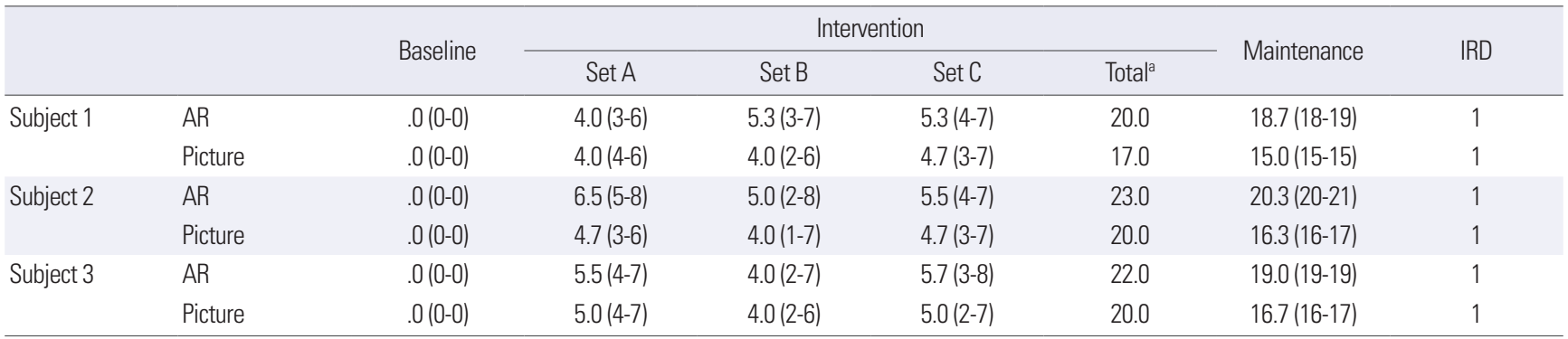

Values are presented as mean (range) of correct response.

$A R=$ augmented reality; $I R D=$ improvement rate difference.

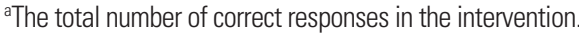

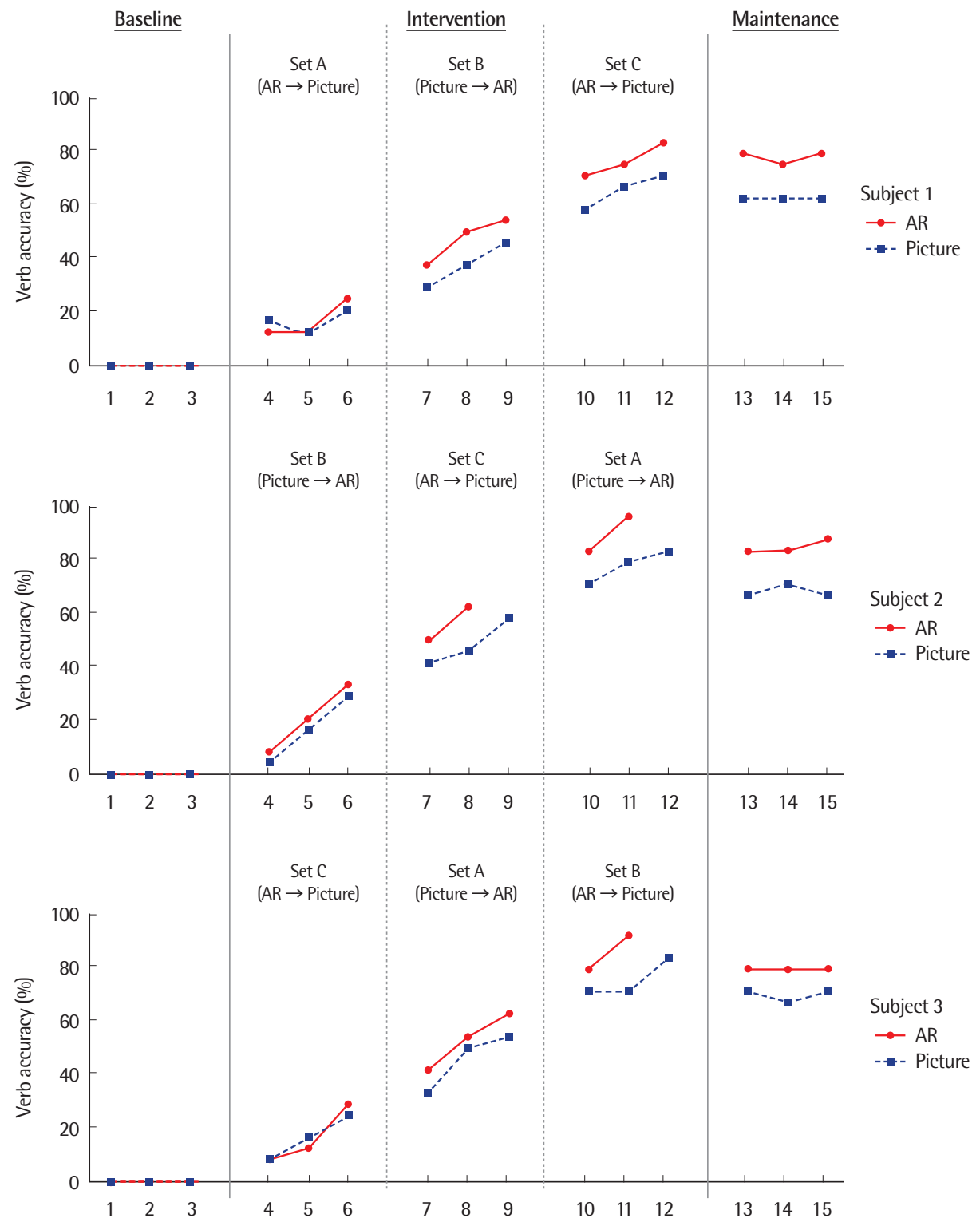

Figure 7. Change of verb accuracy by intervention using alternating treatment design.

$A R=$ augmented reality. 
하여, 교대반복중재로 동사학습을 위한 증강현실 기반 중재와 그 림카드 기반 중재를 실시하였으며 두 중재 간의 어휘정확도, 몰입 도, 학습 흥미도를 비교 분석하였다.

\section{증강현실과 그림카드 기반 중재 간의 어휘정확도}

교대중재설계로 증강현실과 그림카드 기반 중재를 단순언어장애 아동의 동사학습에 적용한 결과는 다음과 같다(Table 3, Figure 7).

대상자 1 의 어휘정확도는 기초선 단계에서 증강현실과 그림카드 중재 각각 $0 \%, 0 \%$ 였고, 중재 단계에서 $83 \%$ (세트 A: $75 \%$, 세트 B: $87.5 \%$, 세트 C: $87.5 \%$ ), 70.8\% (세트 A: $62.5 \%$, 세트 B: $75 \%$, 세트 C: $75 \%)$, 유지 단계에서 $77.8 \%, 62.5 \%$ 로 나타났다. 중재 단계에서 증강 현실은 9회기, 그림카드 중재는 9회기가 소요되었으며 증강현실 기 반 중재의 세트 B와 C를 제외한 세트에서 목표준거 $80 \%$ 에 도달하 지 못하였다. 두 중재 모두 중재효과 크기 1로 높은 효과를 나타내 었으며 어휘정확도는 기초선 단계를 기준으로 증강현실 기반 중재 가 그림카드 기반 중재에 비하여 $15.3 \%$ 더 높은 향상을 보였다.

대상자 2 의 어휘정확도는 기초선 단계에서 증강현실과 그림카드 중재 각각 $0 \%, 0 \%$ 였고, 중재 단계에서 $83.3 \%$ (세트 A: $100 \%$, 세트 B: $100 \%$, 세트 C: $87.5 \%$ ), $83.3 \%$ (세트 A: $87.5 \%$, 세트 B: $87.5 \%$, 세트 C: $75 \%)$, 유지 단계에서 $84.7 \%, 68.1 \%$ 로 나타났다. 중재 단계에서 증강 현실은 7회기, 그림카드 중재는 9회기가 소요되었으며 그림카드 기 반 중재의 세트 $\mathrm{A}$ 를 제외한 모든 세트에서 목표준거 $80 \%$ 에 도달하 였다. 두 중재 모두 중재효과 크기 1 로 높은 효과를 나타내었으며 어휘정확도는 기초선 단계를 기준으로 증강현실 기반 중재가 그림 카드 기반 중재에 비하여 $16.7 \%$ 더 높은 향상을 보였다.

대상자 3 의 어휘정확도는 기초선 단계에서 증강현실과 그림카드 중재 각각 $0 \%, 0 \%$ 였고, 중재 단계에서 $91.7 \%$ (세트 A: $100 \%$, 세트 B: $87.5 \%$, 세트 C: $87.5 \%$ ), $83.3 \%$ (세트 A: $87.5 \%$, 세트 B: $87.5 \%$, 세트 C:
75\%), 유지 단계에서 $79.1 \%, 69.4 \%$ 로 나타났다. 중재 단계에서 증강 현실은 11 회기, 그림카드 중재는 11 회기가 소요되었으며 증강현실 기반 중재의 세트 B와 $\mathrm{C}$ 를 제외한 세트에서 목표준거 $80 \%$ 에 도달 하지 못하였다. 두 중재 모두 중재효과 크기 1 로 높은 효과를 나타 내었으며 어휘정확도는 기초선 단계를 기준으로 증강현실 기반 중 재가 그림카드 기반 중재에 비하여 $16.7 \%$ 더 높은 향상을 보였다.

증강현실 중재가 선행한 세트에서는 후행하는 그림카드 중재의 정확도가 간헐적으로 높게 나타났으나 그림카드 중재가 선행한 회 기 내에서는 후행하는 증간현실 기반 중재의 어휘정확도가 더 높게 나타났다. 세 대상자 모두 그림카드 중재의 어휘목록 중 '굴리다', '눕다', '기어가다'에서 오반응을 보인 반면, 증강현실 기반에서는 대상자 2,3 이 정반응을 나타내었다.

\section{증강현실과 그림카드 기반 중재 간의 몰입도 비교}

증강현실 기반 중재와 그림카드 기반 중재의 몰입 척도를 살펴본 결과(Figure 8), 세 대상자의 전체 평균점수는 증강현실 기반 중재 와 그림카드 기반 중재에서 각각 3.9, 3.2 하위항목 중 문제해결과정 에서 각각 $3.0,3.2$, 과제에 대한 집중은 $3.8,3.0$, 자의식 상실은 4.3 , 3.0 , 시간전이는 $4.3,3.5$ 로 나타났다.

대상자 1 의 전체 평균몰입점수는 증강현실과 그림카드 기반 중 재에서 각각 $3.8,3.1$, 문제해결과정에서 $3.0,3.5$, 과제에 대한 집중 에서 4.0.3.0, 자의식 상실에서 4.0, 3.0, 시간전이에서 4.0, 3.0으로 나타났다. 대상자 2의 전체 평균몰입점수는 증강현실과 그림카드 기반 중재에서 각각 $4.3,3.1$, 문제해결과정에서 $3.0,3.0$, 과제에 대한 집중에서 4.0.3.0, 자의식 상실에서 5.0,3.0, 시간전이에서 4.3, 3.5으 로 나타났다. 대상자 3 의 전체 평균몰입점수는 증강현실과 그림카 드 기반 중재에서 각각 $3.6,3.3$, 문제해결과정에서 $3.0,3.0$, 과제에 대한 집중에서 3.5. 3.0, 자의식 상실에서 4.0, 3.0, 시간전이에서 4.0,

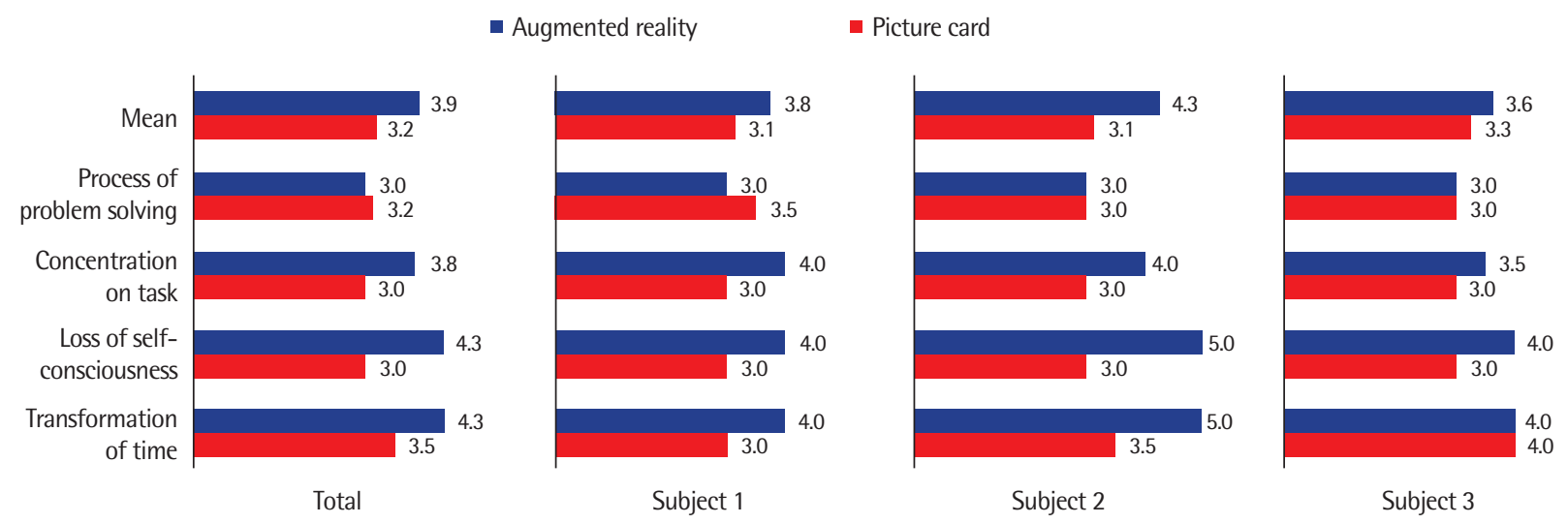

Figure 8. Comparison of learning flow between augmented reality and picture card-based intervention. 

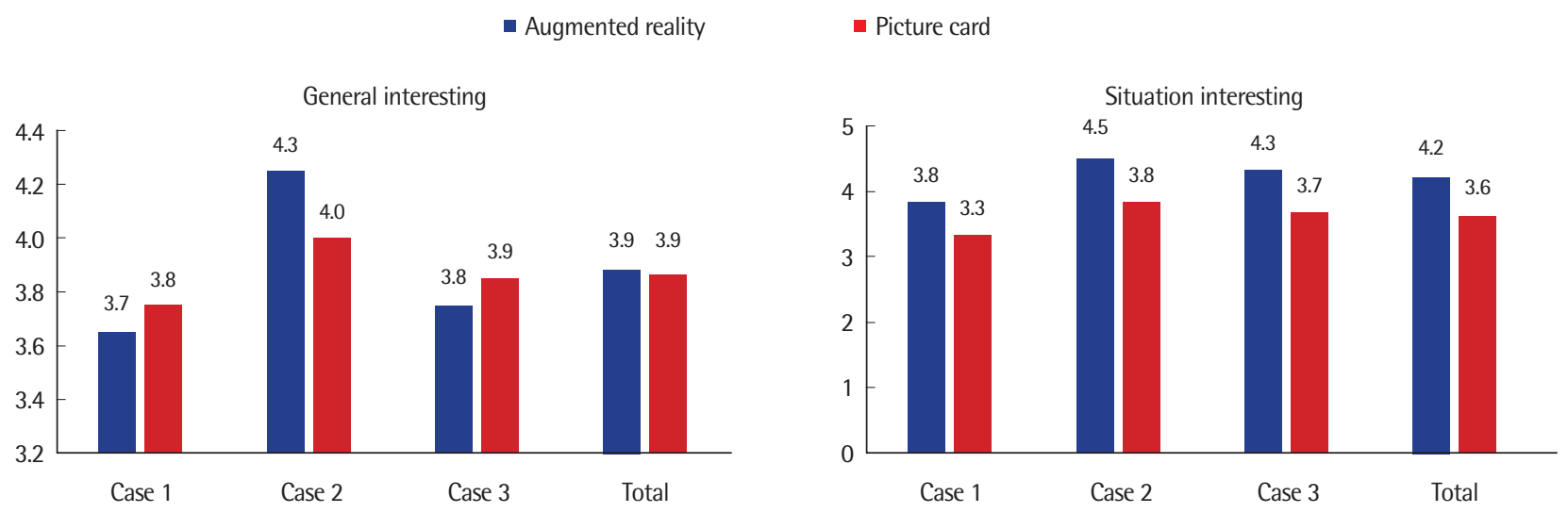

Figure 9. Comparison of learning interesting between augmented reality and picture card based intervention.

4.0으로 나타났다.

\section{증강현실과 그림카드 기반 중재 간의 흥미도 비교}

증강현실 기반 중재와 그림카드 기반 중재의 학습 흥미도를 살펴 본 결과(Figure 9), 세 대상자의 학습 흥미도 전체 평균점수는 각각 $4.0,3.8$ 로 나타났으며 하위항목에서 일반적 흥미의 점수는 각각, $3.9,3.9$, 상황 흥미는 각각 $4.2,3.6$ 으로 나타났다.

대상자 1 의 학습 흥미도 전체 점수는 증강현실과 그림카드 기반 중재에서 각각 $3.7,3.7$ 이었으며 일반적 흥미는 각각 $3.7,3.8$, 상황 흥 미는 각각 $3.8,3.3$ 이었다. 대상자 2 의 학습 흥미도 전체 평균점수는 증강현실과 그림카드 기반 중재에서 각각 $4.3,4.0$ 이었으며 일반적 흥미는 각각 $4.3,4.0$, 상황 흥미는 각각 $4.5,3.8$ 이었다. 대상자 3 의 학습 흥미도 전체 평균점수는 증강현실과 그림카드 기반 중재에서 각각 $3.8,3.9$ 이었으며 일반적 흥미는 각각 $3.75,3.85$, 상황 흥미는 각 각 $4.3,3.7$ 이었다.

\section{논의 및 결론}

컴퓨터 기술의 발달과 함께 장애영역에서도 디자인 인터페이스, 개별화된 애플리케이션 개발, 사용성의 증진 등, $\mathrm{HCI}$ 를 고려한 새 로운 도전들이 시도되고 있다(Schultheis \& Rizzo, 2001). 언어치료 또한, 자폐 스펙트럼과 지적장애 등을 중심으로 증강현실과 가상 현실 등을 이용한 중재가 활발히 연구되고 있으며, 장애를 가진 대 상자들에게 증거기반 중재로 활용될 수 있는지에 대하여 논의되고 있다. 그러나 현재까지 많은 연구들이 이러한 기술이 제공하는 구 체적 이점보다 기술의 구현에 초점이 맞추어져 있다.

따라서 이 연구에서는 임상적 접근이 용이하고 이후 다양한 장
애영역으로 확장이 가능한 증강현실 콘텐츠 플랫폼을 개발하고 다른 도구를 이용한 중재와 비교하여 증강현실이 가질 수 있는 장 점을 살펴보고자 하였다.

일반적으로 증강현실 애플리케이션에는 개체 인식을 위하여 마 커 기반 추적이 많이 사용되고 있지만 본 연구에서는 특징점 추출 을 이용한 모델 기반 추적 알고리즘을 적용하였다. 마커 기반 추적 은 개체 선택을 쉽게 확장할 수 있고 개체의 본체에서 마커 배치를 차감(offsetting)함으로써 손 폐색의 영향에서 자유롭다는 장점이 있다(Bai et al., 2015). 그러나 마커 기반 추적을 위해서는 원하는 개 체에 대한 마커의 제작이 추가적으로 필요하고 최근 컴퓨터 비전 추적 기술의 발달로 마커 기반과 비교하여 제한된 공간 내에서 특 징점 추출 또한 충분한 인식률을 확보할 수 있다(Carmigniani et al., 2011). 특징점 추출을 이용 시 기존에 사용하고 있던 그림카드 를 활용할 수 있어 마커 인식에 비하여 개체의 확장성이 우수하며 그림카드를 위한 중재와 증강현실을 위한 중재 모두에 단일 카드를 활용할 수 있다.

증강현실 기반 중재와 그림카드 기반 중재는 대상자 모두에서 중 재효과가 높게 나타났으며 어휘정확도에서 증강현실 기반 중재가 그림카드 기반 중재보다 더 나은 진전을 보였다. Bai 등(2015)과 Herrera 등(2008)은 증강현실 기반 중재가 컴퓨터를 사용하지 않 은 일반적(비컴퓨터) 기반 중재보다 더 나은 진전을 보였다고 하였 으며 da Cunha 등(2018)의 문헌고찰에 의하면 증강현실과 가상현 실을 이용한 중재의 연구들에서 $60 \%$ 이상 긍정적인 효과가 있는 것으로 보고되고 있다. 그러나 Bae 등(2014)의 연구에서는 전통적 방법의 언어치료와 증강현실 모두 진전을 보였으나 두 방법 간의 진 전효과는 유의한 차이가 없는 것으로 나타났다. 또한, Lee와 Ryu (2014)는 학습장애 아동의 치료에서 전통적 접근법과 증강현실을 
함께 사용하였을 때 더 효과가 높다고 하였다. 이와 같이, 증거기반 중재의 관점에서 전통적 중재방법보다 증강현실이 더 효과적이라 고 보기에는 아직까지 중재효과에 대하여 합의된 바가 없으며 매체 의 영향보다 교수학습설계에 따른 차이가 학업성취에 더 많은 영향 력을 미칠 수 있다(Bae et al., 2014; Noh, Jee, \& Lim, 2010).

특정 동작동사의 치료에서는 증강현실 기반 중재가 그림카드 기 반 중재보다 효과적이었다. 증강현실 중재는 회기 내에서 후행하는 경우, 선행한 그림카드 중재보다 항상 더 높은 어휘정확도를 나타 낸 반면, 그림카드 중재가 후행하는 경우에는 선행한 증강현실 중 재와 비교하여 간헐적으로 더 낮은 어휘정확도를 나타내었다. 또 한, 그림카드 중재에서 대상자들 모두 '굴리다', '눕다', '기어가다'에 서 오반응을 보인 반면, 증강현실 중재에서는 정반응을 보여 동사 학습에 증강현실이 그림카드 중재보다 더 큰 긍정적인 영향을 미친 것으로 볼 수 있다. Kim, Kim과 Park (2005)과 Schlosser 등(2012) 의 연구에서 애니메이션이나 동영상 등을 이용한 중재는 정적인 그 림카드에 비해 동적인 움직임을 나타내는 동사의 학습에 효과적인 것으로 나타났다. 증강현실을 이용한 중재 또한, 증강을 통하여 시 공간적인 제약을 벗어나 현실세계에 가상의 움직임을 제공하여 주 고 실물 인터페이스와 상호작용하게 함으로 기존의 서지 기반 중재 에서 표현하기 어려운 관형어나 부사어와 같은 수식어, 감정과 움직 임 등의 동사, 추상적인 개념 등에 적합하며 학습효과를 높이는 중 재로써 활용할 수 있다(Chen et al., 2016).

증강현실과 그림카드 기반 중재는 언어치료 자체에 대한 일반적 흥미에서 긍정적인 결과를 나타내었다. 중재 자체에 대한 흥미를 의 미하는 상황적 흥미는 증강현실 기반 중재가 더 높게 나타나 중재 가 아동의 동기유발과 능동적 치료참여 긍정적 영향을 미친 것으 로 볼 수 있다(Noh et al., 2010). 상황적 흥미는 일반적 학습 흥미의 요인으로 작용하기 때문에 증강현실의 매체특성은 치료의 흥미를 유발하게 되고 언어치료 자체에 대한 흥미로 이어질 수 있다. 증강 현실 기술은 실제 환경과 가상의 세계를 분리하지 않고 상호작용하 기 때문에 사용자에게 감각적 집중을 이끌어내면서 부가적인 지식 을 제공하며 주체적으로 그림카드 또는 디스플레이를 주체적으로 조작하며 주도적인 학습 참여를 유도할 수 있다(Bae et al., 2014; Kye \& Kim, 2008).

증강현실 기반 중재는 그림카드 중재보다 더 높은 몰입을 보였다. 학습몰입은 학습행위에 몰두하여 자존감과 만족감이 향상되는 최적의 경험을 갖게 되는 상태를 의미한다(Shelton \& Hedley, 2002). 증강현실 기반 실감형 학습기술을 이용한 스마트러닝 시스템은 $3 \mathrm{D}$ 콘텐츠를 책이나 마커와 같은 인쇄물에 증강시켜 학생들로 하 여금 몰입감을 느끼면서 학습할 수 있는 환경을 제공할 수 있다. 몰
입되어 있는 심리적 상태는 중재 과정 자체에 집중하게 되고 자발 적 학습으로 이어질 수 있는 주요한 내재적 동기로 작용한다. 이와 같이, 증강현실은 지식의 제공과 함께 행위 자체에 대한 즐거움과 몰입을 제공할 수 있기 때문에 기존의 e-러닝 시스템을 넘어 u-러닝 시스템을 발전해가고 있다.

또한, 증강현실은 다양한 저작도구를 통하여 증강현실 기반의 학습환경에 사용할 콘텐츠를 쉽게 제작할 수 있다(CHO Alliance, 2016). 가상현실 기반으로 치료 콘텐츠를 개발할 경우, 모든 가상의 사물과 환경을 모델링하여야 하기 때문에 콘텐츠 창출에 많이 시 간과 비용이 소모되고 사실성이 부족하여 효과가 떨어질 수 있다. 반면에 증강현실은 상호작용을 하거나 실제에서는 존재하지 않는 필요 객체만을 모델링하고 그 이외의 환경 객체는 실제 객체를 그 대로 사용할 수 있어 모델링이 간편하며 현실세계를 바탕으로 가 상의 오브젝트와 상호작용할 수 있어 보다 나은 현실감을 제공하 여 준다.

증강현실은 하나의 기술로서 어떻게 사용되는가에 따라 그 효과 가 달라질 수 있다. Clark (1983)는 미디어는 정보제공을 위한 전달 수단일 뿐 실제 학습 수행력에는 영향을 미치지 않는다고 하였고 이러한 맥락에서 공학적 수단보다 치료설계 방법이 학습효과에 더 큰 영향을 미칠 수 있다(Kirkley \& Kirkley, 2005). Noh 등(2010)의 연구를 보면 증강현실을 이용한 교과학습이 학습동기와 사용성에 는 영향을 미쳤지만 학업성취도에는 영향을 미치지 않았다고 보고 하였다. 따라서, $\mathrm{HCI}$ 와 컴퓨터 비전 기술이 향상된 증강현실 플랫 폼의 개발도 중요하지만 이러한 도구를 지원할 수 있는 다양한 콘 텐츠와 학습전략의 개발 또한 언어치료 중재방법으로서의 증강현 실에 중요한 부분이다.

결론적으로, 증강현실은 컴퓨터와 영상 기술의 발달과 더불어 여러 분야에 급속하게 확대되고 있으며 증강현실 기술과 교육 콘텐 츠의 결합은 새로운 형태의 치료도구로 주목 받고 있다. 동사와 감 정 등 기존의 그림카드로는 제한이 있었던 어휘들의 학습에 효과 적이며 혼합현실의 제공은 보다 현실적인 감각을 제시하며 아동의 학습의도를 향상시키는 데 도움이 된다. 그러나 증강현실 기술은 적합한 교수학습 계획 및 치료프로그램이 뒷받침될 때 최적의 중 재효과를 얻을 수 있을 것이다.

후속연구에서는 다양한 플랫폼에서 호환 가능한 웹 버전의 애 플리케이션 개발이 필요하며 사용자가 그림카드와 증강 개체를 graphic user interface (GUI) 기반에서 쉽게 매칭할 수 있게 하여 사용성을 개선한 프로그램 개발이 필요할 것으로 사료된다. 또한, 보다 많은 대상자 수와장애군에서의 한 연구가 이어져야 할 것이다. 
In-Ho Bae, et al. • Markless Augmented Reality based Speech Language Therapy

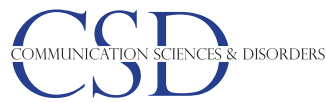

\section{REFERENCES}

Ahn, B. K., Bae, I. H., Park, H. J., \& Kwon, S. B. (2018). The efficacy of augmented reality based speech language therapy program on verbal expression vocabulary improvement in children with intellectual disabilities. Journal of Speech-Language \& Hearing Disorders, 27, 111-124.

Bacca, J., Baldiris, S., Fabregat, R., \& Graf, S. (2014). Augmented reality trends in education: a systematic review of research and applications. Journal of Educational Technology \& Society, 17, 133-149.

Bae, I. H., Park, H. J., Kim, G. H., \& Kwon, S. B. (2014). Educational application of speech therapy program based on augmented reality. Journal of Speech \& Hearing Disorders, 23, 139-152.

Bai, Z., Blackwell, A. F., \& Coulouris, G. (2015). Using augmented reality to elicit pretend play for children with autism. IEEE Transactions on Visualization and Computer Graphics, 21, 598-610.

Carmigniani, J., Furht, B., Anisetti, M., Ceravolo, P., Damiani, E., \& Ivkovic, M. (2011). Augmented reality technologies, systems and applications. Multimedia Tools and Applications, 51, 341-377.

Chen, C. H., Lee, I. J., \& Lin, L. Y. (2016). Augmented reality-based video-modeling storybook of nonverbal facial cues for children with autism spectrum disorder to improve their perceptions and judgments of facial expressions and emotions. Computers in Human Behavior, 55, 477-485.

CHO Alliance. (2016). VR, AR technology and application market trend and participant business strategy (pp. 267-271). Seoul: CHO Alliance.

Choi, E. J., Kim, Y. T., Yeon, S. J., Kim, J., \& Hong, K. H. (2016). Effects of robot and computer-based intervention on learning action word symbols of AAC for children with autism spectrum disorder. Communication Sciences \& Disorders, 21, 744-759.

Choi, J. I., Kim, K. R., \& Kim, T. Y. (2013). A situational training system based on augmented reality for developmentally disabled people. Journal of Korea Multimedia Society, 16, 629-636.

Chung, P. J., Vanderbilt, D. L., \& Soares, N. S. (2015). Social behaviors and active videogame play in children with autism spectrum disorder. Games for Health Journal, 4, 225-234.

Clark, R. E. (1983). Reconsidering research on learning from media. Review of Educational Research, 53, 445-459.

da Cunha, R. D., Neiva, F. W., \& da Silva, R. L. D. S. (2018). Virtual reality as a support tool for the treatment of people with intellectual and multiple disabilities: a systematic literature review. Revista de Informática Teórica e Aplicada, 25, 67-81. da Silva, C. A., Fernandes, A. R., \& Grohmann, A. P. (2014). STAR: speech therapy with augmented reality for children with autism spectrum disorders. In Cordeiro et al. (Eds.), Enterprise information systems (pp. 379-396). Cham: Springer.

Herrera, G., Alcantud, F., Jordan, R., Blanquer, A., Labajo, G., \& De Pablo, C. (2008). Development of symbolic play through the use of virtual reality tools in children with autistic spectrum disorders: two case studies. Autism, $12,143-157$.

Hwang, B. M., Kwon, S. B., Kim, S. J., and Shin, B. J. (2017). A basic study of verbs list for vocabulary learning based on augmented reality. Journal of Rehabilitation Research, 21, 233-246.

Kang, D. H., Park, H. J., Song, B. D., Kim, J. D., \& Shin, B. H. (2015). Design and development of an articulation and phonological disorder assessment system using augmented reality. Journal of Speech \& Hearing Disorders, 24, 87-94.

Kim, Y. G., \& Kwon, S. B. (2017). Trends analysis of augmented reality technology applied in special education. Journal of Special Education \& Rehabilitation Science, 56, 127-146.

Kim, Y. T. (2002). Diagnosis and treatment of language disorders in children. Seoul: Hakjisa.

Kim, Y. T., Kim, Y. R., \& Park, S. H. (2005). The effect of animation of CAI on the stimulus generalization to line drawing and the MLU. Journal of Speech and Hearing Disorders, 14, 81-96.

Kim, Y. T., Sung, T. J., \& Lee, Y. K. (2003). Preschool receptive-expressive language scale (PRES). Seoul: Seoul Community Rehabilitation Center.

Kirkley, S. E., \& Kirkley, J. R. (2005). Creating next generation blended learning environments using mixed reality, video games and simulations. TechTrends, 49, 42-53.

Kye, B. K., \& Kim, Y. S. (2008). Investigation on the relationships among media characteristics, presence, flow, and learning effects in augmented reality based learning. Journal of Educational Technology, 24, 193-224.

Lee, H. J., Kang, M. K., \& Kim, Y. T. (2013). Current practice and support needs in smart media perceived by the mothers of children with communication difficulties. Communication Sciences \& Disorders, 18, 163-171.

Lee, M. J. (2018). Effects of language intervention using application based on augmented reality for verbal expressions of language delayed children (Master's thesis). Honam University, Gwangju, Korea.

Lee, S. K. (2015). Teachers' interaction to young children, play flow \& self-efficacy of young children according to early childhood teachers' teaching flow (Doctoral dissertation). Wonkwang University, Iksan, Korea. 
Lee, T. S., \& Ryu, J. Y. (2014). The effects of augmented reality based language intervention program on language abilities and learning aptitudes of students with learning disabilities. The Korea Journal of Learning Disabilities, 11, 31-52.

Noh, K. H., Jee, H. K., \& Lim, S. H. (2010). Effect of augmented reality contents based instruction on academic achievement, interest and flow of learning. Journal of the Korea Contents Association, 10, 1-13.

Pae, S., \& Kwak, K. C. (2011). Korean MacArthur-Bates Communicative Development Inventories (KM-B CDI). Seoul: Mindpress.

Park, H., Kwak, K., \& Park, K. (1996). Korean-Wechsler Preschool and Primary Scale of Intelligence (K-WPPSI). Seoul: Seoul Community Rehabilitation Center.

Parker, R. I., Vannest, K. J., \& Brown, L. (2009). The improvement rate difference for single-case research. Exceptional Children, 75, 135-150.
Read, J. C., \& MacFarlane, S. (2006). Using the fun toolkit and other survey methods to gather opinions in child computer interaction. Proceedings of the 2006 Conference on Interaction Design and Children, 81-88.

Schlosser, R. W., Shane, H., Sorce, J., Koul, R., Bloomfield, E., Debrowski, L., ... \& Neff, A. (2012). Animation of graphic symbols representing verbs and prepositions: effects on transparency, name agreement, and identification. Journal of Speech, Language, and Hearing Research, 55, 342-358.

Schultheis, M. T., \& Rizzo, A. A. (2001). The application of virtual reality technology in rehabilitation. Rehabilitation Psychology, 46, 296-311.

Shelton, B. E., \& Hedley, N. R. (2002). Using augmented reality for teaching earth-sun relationships to undergraduate geography students. Proceedings of the 1st IEEE International Workshop Augmented Reality Toolkit, 8.

Snell, M. E., \& Brown, F. (2008). Instruction of students with severe disabilities (6th ed., Park \& Han, Trans.). Seoul: Sigmapress. 
Appendix 1. 강화된 환경중심 언어중재

\begin{tabular}{|c|c|c|c|}
\hline \multicolumn{2}{|l|}{ 전략 } & 설명 & 예시 \\
\hline \multirow[t]{6}{*}{ 환경조절 } & 흥미 있는 자료 & 아동의 주의집중과 흥미를 유발할 수 있는 사물을 이용한다. & $\begin{array}{l}\text { 아동의 주의집중을 흩트릴 만한 주변환경을 배제하고 그림카드와 증강 } \\
\text { 현실이 중심이 된 치료환경을 구성한다. }\end{array}$ \\
\hline & 닿지 않는 위치 & $\begin{array}{l}\text { 아동의 시야 내에 자료를 두되 아동의 손에 닿지 않는 곳에 } \\
\text { 둔다. }\end{array}$ & 증강현실과 그림카드를 치료사 앞에 두고 아동의 손에 닿지 않게 한다. \\
\hline & 도움 & $\begin{array}{l}\text { 아동이 자료를 조작하기 위하여 도움을 요청할 상황을 만든 } \\
\text { 다. }\end{array}$ & $\begin{array}{l}\text { 그림카드와 증강현실 카드를 잘 안 열리는 투명아크릴 통에 넣어두거나 } \\
\text { 증강용 애플리케이션을 실행시켜 놓지 않는다. }\end{array}$ \\
\hline & 선택 & $\begin{array}{l}\text { 아동이 발화를 시작하도록 하기 위하여 언어적/비언어적 선 } \\
\text { 택 기회를 준다. }\end{array}$ & 증강현실 또는 그림카드를 제시하고 아동이 선택하기를 기다린다. \\
\hline & 중요요소 빼기 & $\begin{array}{l}\text { 아동이 과제를 완성하도록 제시하고 그 활동의 중요한 요소 } \\
\text { 를 뺀다. 그리고 나서 활동을 완성하도록 한다. }\end{array}$ & $\begin{array}{l}\text { 아동에게 8장의 카드를 꽃을 수 있는 트레이를 주고 몇 장을 빼고 아동 } \\
\text { 에게 그림카드 또는 증강현실 카드를 제공한다. }\end{array}$ \\
\hline & 불충분한 자료 & $\begin{array}{l}\text { 적은 수의 자료를 제공하여 아동이 추가적인 자료를 요구하 } \\
\text { 도록 만든다. }\end{array}$ & $\begin{array}{l}\text { 아동에게 몇 장의 카드를 할지 물은 후 치료사는 아동에게 하나의 카드 } \\
\text { 만을 주고 다른 카드를 더 요구하기를 기다린다. }\end{array}$ \\
\hline \multirow[t]{9}{*}{$\begin{array}{l}\text { 반응적 } \\
\text { 상호작용 }\end{array}$} & 아동 주도에 따르기 & $\begin{array}{l}\text { 아동의 행동이나 말과 유사한 언어/비언어적 행동을 하며 아 } \\
\text { 동 주도에 따른다. 아동의 발화를 기다려주고 경청하고, 말 } \\
\text { 과 행동을 모방하고, 지시나 질문은 피한다 }\end{array}$ & $\begin{array}{l}\text { 아동과 함께 그림카드나 증강현실을 보며 “친구가 아침에 일어났네”라 } \\
\text { 고 말한다. 아동이 다른 카드를 집어 들거나 화면을 이동한다면 그 카 } \\
\text { 드에 대한 이야기를 한다. }\end{array}$ \\
\hline & 공동 관심 형성하기 & $\begin{array}{l}\text { 아동과 치료사가 같은 활동에 참여한다. 아동이 활동을 바꾸 } \\
\text { 면 치료사도 아동이 선택한 활동으로 이동한다 }\end{array}$ & $\begin{array}{c}\text { 아동이 “잡다” 카드를 잡으면 아동 또는 카드 등을 잡으며 “잡았다”라고 } \\
\text { 말하며 활동에 개입한다. 또는 증강현실을 같이 조작한다. }\end{array}$ \\
\hline & 정서 일치시키기 & $\begin{array}{l}\text { 아동의 기분과 태도가 적절할 때 아동의 정서를 맞추어가며 } \\
\text { 반응한다. }\end{array}$ & $\begin{array}{l}\text { 아동이 웃으면 치료사도 웃으며 바라보고 아동이 흥분하면 같이 흥분된 } \\
\text { 모습을 보인다. }\end{array}$ \\
\hline & 상호적 주고받기 & $\begin{array}{l}\text { 치료사와 아동의 상호작용에서 아동과 치료사가 교대로 대화 } \\
\text { 를 나누거나 사물을 주고받는다. }\end{array}$ & $\begin{array}{l}\text { (1) 사물 주고받기: 증강현실 또는 그림카드로 밀거나 던지기 놀이를 하 } \\
\text { 며 주고받는다. } \\
\text { (2) 대화 주고받기: 치료사가 증강현실을 보여주거나 그림카드와 함께 } \\
\text { 행위를 보여주며 “친구가 박수치네”라고 말할 때 아동이 박수치는 행 } \\
\text { 위 모방하면 “말로도 해야지 뭐라고?” 질문하고 아동은 “박수”라고 말 } \\
\text { 한다. }\end{array}$ \\
\hline & 시범 보이기 & $\begin{array}{l}\text { (1) 평행적 발화기법: 치료사는 아동의 입장에서 느끼고, 생각 } \\
\text { 하는 것에 대해 아동이 말할 만한 문장으로 말해준다. } \\
\text { (2) 혼잣말기법: 치료사는 자신의 입장에서 보고 듣고 느낀 것 } \\
\text { 에 대해 아동에게 들려준다. }\end{array}$ & $\begin{array}{l}\text { (1) 평행적 발화 기법: 아동이 ‘잡다’ 카드를 잡으면 치료사는 “ } 00 \text { 가 카드 } \\
\text { 를 잡았네”라고 한다. } \\
\text { (2) 혼잣말 기법” 치료사가 ‘잡다’ 카드를 잡으며 “선생님이 카드를 잡았 } \\
\text { 네”라고 말한다. }\end{array}$ \\
\hline & 확장하기 & $\begin{array}{l}\text { 아동의 발화에 대해 적절한 구문론적, 의미론적 정보를 추가 } \\
\text { 해서 보다 완성된 형태로 다시 들려준다. }\end{array}$ & $\begin{array}{l}\text { 아동: 물 } \\
\text { 치료사: 물이 쏟아졌어요 }\end{array}$ \\
\hline & 아동 모방하기 & $\begin{array}{l}\text { 아동의 행동이나 말을 모방하여 아동의 말이 전달되었다는 } \\
\text { 것을 알려주거나 아동과 공동관심을 형성한다. }\end{array}$ & $\begin{array}{l}\text { 아동: 빵 } \\
\text { 치료사: 그래, 빵이야 }\end{array}$ \\
\hline & $\begin{array}{l}\text { 아동발화에 } \\
\text { 반응하기 }\end{array}$ & $\begin{array}{l}\text { 아동의 말에 대해 “응”, “그랬어?”, “그래” 등과 같이 말해주거 } \\
\text { 나 고개를 끄덕거려 줌으로써 아동의 발화를 인정해 주고, } \\
\text { 이해했다는 것을 알려준다. }\end{array}$ & $\begin{array}{l}\text { 아동: 도와줘 } \\
\text { 치료사: 그래, 선생님이 도와줄게 }\end{array}$ \\
\hline & 아동반응 기다리기 & $\begin{array}{l}\text { 언어적 자극을 제공하고 이에 반응할 수 있도록 최소한 } 5 \text { 초 } \\
\text { 이상의 반응 시간을 두어 아동의 반응을 기다려준다. }\end{array}$ & $\begin{array}{l}\text { 치료사가 “00아, 무슨 카드 줄까?”라고 질문하였을 때 아동이 무반응이 } \\
\text { 면 5초 이상 기다리고 다시 질문한다. }\end{array}$ \\
\hline \multirow[t]{3}{*}{$\begin{array}{l}\text { 환경중심 } \\
\text { 언어중재 } \\
\text { 전략 }\end{array}$} & 아동중심 시범 & $\begin{array}{l}\text { 아동중심의 언어적 시범으로, 아동의 관심에 따라서 그 행동 } \\
\text { 이나 사물에 관심을 보이고 참여하면서 적절한 언어를 시 } \\
\text { 범 보인다. }\end{array}$ & $\begin{array}{l}\text { 아동은 치료사가 가지고 있는 카드를 바라보거나 증강현실 디스플레이 } \\
\text { 로 다른 곳을 비추려고 할 때 그 카드에 대해 이야기 하면서 목표단어 } \\
\text { 에 대한 언어적 시범을 보여주고 아동이 정반응 시 강화를 제공한다. }\end{array}$ \\
\hline & 선반응 요구-후시범 & $\begin{array}{l}\text { 아동과 함께 활동에 참여하면서 구두로 언어적 반응을 요구 } \\
\text { 해 본 후 시범을 보인다. }\end{array}$ & $\begin{array}{l}\text { 아동에게 먼저 “친구가 뭐하고 있어?", "이게 뭐야?” 등으로 반응을 요구 } \\
\text { 한다. 아동이 정반응하면, 즉각적인 강화로 언어를 확장하고 오반응 } \\
\text { 또는 무반응을 보이면, 두 번째 요구나 시범을 제시한다. }\end{array}$ \\
\hline & 시간지연 & $\begin{array}{l}\text { 아동과 함께하는 활동 중에 아동의 언어적 반응을 기다려줌 } \\
\text { 으로써 아동이 말을 해야 되는 상황임을 알고 말을 하면 적 } \\
\text { 절한 시범을 보여준다. }\end{array}$ & $\begin{array}{l}\text { 치료사는 그림카드 또는 증강현실을 보며 “친구가 뭐하고 있어?”라고 } \\
\text { 질문하고 아동이 대답을 하지 않고 놀이상황을 유지하려고 하면 그림 } \\
\text { 카드 또는 증강현실을 가리며 } 5 \text { 초 정도 기다린다. 아동이 적절히 대답 } \\
\text { 하면 강화와 함께 놀이활동을 이어간다. }\end{array}$ \\
\hline
\end{tabular}

$\operatorname{Kim}$ (2002), Snell \& Brown (2008)에서 수정. 


\section{국문초록}

\section{증강현실 기반 언어치료를 위한 플랫폼의 개발}

배인호 $\cdot$ 이주아 ${ }^{2} \cdot$ 박희준 ${ }^{3} \cdot$ 권순복 ${ }^{4}$

${ }^{1}$ 양산부산대학교병원 이비인후과, ${ }^{2}$ 채움 언어심리감각통합발달센터, ${ }^{3}$ 춘해보건대학교 언어재활과, ${ }^{4}$ 부산대학교 언어정보학과

배경 및 목적: 증강현실은 가상현실과 구별되는 개념으로 가상세계를 현실세계에 중첩시켜 상호작용하게 하는 기술이다. 최근 언어치 료 분야에서도 증강현실은 전통적인 치료 패러다임을 보완하기 위한 새로운 매체로서 관심 있게 다루어지고 있다. 본 연구에서는 태블 릿 기반의 마크리스(markless) 증강현실 언어치료 프로그램을 개발하고 증강현실과 그림카드를 이용한 중재의 효과를 비교하고자 하 였다. 방법: 증강현실 애플리케이션은 자연특징 추적 알고리즘을 이용하여 객체를 인식하게 프로그래밍하였으며, 단순언어발달지연 아동 3 명에게 교대중재설계를 사용하여 24 개의 동작동사에 대하여 증강현실과 그림카드 기반 중재를 시행하였다. 두 중재 간의 차이는 어휘정확도, 중재효과 크기, 몰입도, 학습 흥미도로 비교하였다. 결과: 태블릿 기반 증강현실 중재와 그림카드 중재 모두에서 동작동사 어휘력의 향상을 나타내었으며 중재와 유지 단계에서 증강현실 기반 중재가 더 높은 어휘정확도를 나타내었다. 학습몰입은 증강현실 기반 중재가 더 높게 나타내었으며, 일반적 흥미는 두 중재 모두 유사한 결과를 보였으나 상황흥미에서 증강현실 기반 중재가 더 높게 나 타났다. 논의 및 결론: 증강현실과 그림카드 중재 모두 효과적이었으나 증강현실 기반 중재는 기존의 그림카드로 제한이 있었던 어휘들 의 학습에 효과적이었으며, 혼합현실의 제공은 아동의 학습동기와 참여를 향상시키는 데 도움이 되었다. 또한, 마크리스 증강현실 플랫 폼은 콘텐츠의 확장이 용이하여 임상현장에서 증강현실 기반 언어치료 프로그램의 적용에 유용하게 활용될 수 있을 것으로 사료된다.

핵심어: 증강현실, 자연특징추적, 단순언어장애, 동작동사, 태블릿

본 연구는 2015년 대한민국 교육부와한국연구재단의 지원을 받아 수행된 연구임(NRF-2015S1A5B6037281).

\section{참고문헌}

강덕훈, 박희준, 송복득, 김진동, 신범주(2015). 증강현실을 이용한 조음음운장애 검사 시스템 설계 및 구현. 언어치료연구, 24, 87-94.

계보경, 김영수(2008). 증강현실 기반 학습에서 매체특성, 현존감, 학습몰입, 학습효과의 관계 규명. 교육공학연구, 24, 193-224.

김영태(2002). 아동언어장애의 진단 및 치료. 서울: 학지사.

김영태, 김영란, 박소현(2005). 컴퓨터 애니메이션을 활용한 동사습득훈련이 언어지체아동의 선 그림에 대한 자극일반화 및 발화길이에 미치는 효과.

언어치료연구, 14, 81-96.

김영태, 성태제, 이윤경(2003). 취학전 아동의 수용언어 및 표현언어 척도(PRES). 서울: 서울장애인종합복지관.

김유경, 권순복(2017). 특수교육에 적용된 증강현실 기술의 국내외 연구동향 분석. 특수교육재활과학연구, 56, 127-146.

노경희, 지형근, 임석현(2010). 증강현실 콘텐츠 기반 수업이 학업성취, 학습흥미, 몰입에 미치는 효과. 한국콘텐츠학회논문지, 10, 1-13.

박혜원, 곽금주, 박광배(1997). 한국-웩슬러 유아지능검사(K-WPPSI). 서울: 도서출판 특수교육.

배소영, 곽금주(2011). 한국판 맥아더-베이츠 의사소통발달평가(K M-B CDI). 서울: 마인드프레스.

배인호, 박희준, 김근효, 권순복(2014). 증강현실기반 언어치료 프로그램의 교육적 적용. 언어치료연구, 23, 139-152.

안병강, 배인호, 박희준, 권순복(2018). 증강현실기반 언어치료 프로그램이 지적장애아동의 동사 표현 어휘력 향상에 미치는 효과. 언어치료연구, 27,

$111-124$

이명진(2018). 증강현실 기반 어플리케이션을 활용한 언어중재가 언어발달지체 아동의 동사 표현에 미치는 영향. 호남대학교 대학원 석사학위논문. 이선경(2015). 유아교사의 교수몰입도에 따른 유아에 대한 상호작용과 유아의 놀이몰입 및 자기효능감. 원광대학교 대학원 박사학위논문.

이태수, 류재연(2014). 증강현실 기반 언어교육프로그램이 학습장애 학생의 언어능력 및 학습 태도에 미치는 영향. 학습장애연구, 11, 31-52.

이현정, 강민경, 김영태(2013). 어머니가 인식한 자녀의 의사소통 어려움과 스마트미디어 활용 현황 및 요구조사. 언어청각장애연구, 18, 163-1. 
최은정, 김영태, 연석정, 김동준, 홍기형(2016). 교육용 로봇과 컴퓨터를 활용한 자폐범주성장애 아동의 $\mathrm{AAC}$ 동작어 상징 학습 효과. 언어청각장애연 구, 21, 744-759.

최재인, 김경래, 김태영(2013). 발달 장애인을 위한 증강현실 기반 상황훈련 시스템. 멀티미디어 학회논문지, 16, 629-636.

황보명, 권순복, 김선종, 신범주(2017). 증강현실 기반 어휘 지도에서 동사 목록에 대한 기초 연구. 재활복지, 21, 233-246.

$\mathrm{CHO}$ Alliance (2016). 가상현실(VR), 증강현실(AR) 기술 및 응용시장 동향과 참여업체 사업전략(pp. 267-271). 서울: CHO Alliance.

Martha E. Snell, Fredda Brown (2008). 중도장애학생의 교육 6판(박은혜, 한경근 역). 서울: 시그마프레스. 